\title{
Prevalence of drug use during sex among swingers and perceived benefits and risks - a cross-sectional internet survey in the Netherlands
}

Citation for published version (APA):

Evers, Y. J., Dukers-Muijrers, N. H. T. M., Kampman, C. J. G., van Liere, G. A. F. S., Hautvast, J. L. A., Koedijk, F. D. H., \& Hoebe, C. J. P. A. (2020). Prevalence of drug use during sex among swingers and perceived benefits and risks - a cross-sectional internet survey in the Netherlands. Sexually Transmitted Infections, 96(1), 40-46. https://doi.org/10.1136/sextrans-2019-054113

Document status and date:

Published: 01/02/2020

DOI:

10.1136/sextrans-2019-054113

Document Version:

Publisher's PDF, also known as Version of record

Document license:

Taverne

Please check the document version of this publication:

- A submitted manuscript is the version of the article upon submission and before peer-review. There can be important differences between the submitted version and the official published version of record.

People interested in the research are advised to contact the author for the final version of the publication, or visit the DOI to the publisher's website.

- The final author version and the galley proof are versions of the publication after peer review.

- The final published version features the final layout of the paper including the volume, issue and page numbers.

Link to publication

\footnotetext{
General rights rights.

- You may freely distribute the URL identifying the publication in the public portal. please follow below link for the End User Agreement:

www.umlib.nl/taverne-license

Take down policy

If you believe that this document breaches copyright please contact us at:

repository@maastrichtuniversity.nl

providing details and we will investigate your claim.
}

Copyright and moral rights for the publications made accessible in the public portal are retained by the authors and/or other copyright owners and it is a condition of accessing publications that users recognise and abide by the legal requirements associated with these

- Users may download and print one copy of any publication from the public portal for the purpose of private study or research.

- You may not further distribute the material or use it for any profit-making activity or commercial gain

If the publication is distributed under the terms of Article $25 \mathrm{fa}$ of the Dutch Copyright Act, indicated by the "Taverne" license above, 


\title{
Prevalence of drug use during sex among swingers and perceived benefits and risks - a cross-sectional internet survey in the Netherlands
}

\author{
Ymke J Evers (10 , 1,2 Nicole H T M Dukers-Muijrers, ${ }^{1,2}$ Carolina J G Kampman, ${ }^{3}$ \\ Geneviève A F S van Liere (D) , 1,2 Jeannine LA Hautvast, ${ }^{4}$ Femke D H Koedijk, ${ }^{3}$ \\ Christian J P A Hoebe ${ }^{1,2}$
}

\begin{abstract}
- Additional material is published online only. To view please visit the journal online (http://dx.doi.org/10.1136/ sextrans-2019-054113)

'Department of Sexual Health, Infectious Diseases and Environmental Health, South Limburg Public Health Service, Heerlen, The Netherlands ${ }^{2}$ Department of Medical Microbiology, Care and Public Health Research Institute (CAPHRI), Maastricht, The Netherlands

${ }^{3}$ Department of Sexual Health, Twente Public Health Service, Enschede, The Netherlands ${ }^{4}$ Department of Primary and Community Care, Radboud University Medical Center, Nijmegen, The Netherlands
\end{abstract}

\section{Correspondence to}

Ymke J Evers, Sexual Health, Infectious Diseases, and Environmental Health, South Limburg Public Health Service, Heerlen 6400 AA, Netherlands; ymke.evers@ggdzl.nl

Received 30 April 2019 Revised 19 June 2019 Accepted 23 June 2019 Published Online First 12 August 2019

\section{Check for updates}

(c) Author(s) (or their employer(s)) 2020. No commercial re-use. See rights and permissions. Published by BMJ.

To cite: Evers YJ Dukers-Muijrers NHTM Kampman CJG, et al. Sex Transm Infect 2020:96:40-46.

\begin{abstract}
Objectives Drug use during sex has been associated with sexually transmitted infections (STI). While a growing body of research has investigated drug use during sex among men who have sex with men, data in swingers is limited. Swingers are heterosexual couples who have sex with others and singles who have sex with these couples. Our study assessed the prevalence of drug use during sex and perceived benefits and risks among swingers.
\end{abstract}

Methods In 2018, 1005 swingers completed an online questionnaire that was advertised at Dutch swingerwebsites. We assessed the associations between drug use during sex $<6$ months (any drug use excluding alcohol and erection medicines) and sociodemographic characteristics, alcohol use and condomless sex using backward multivariable logistic regression analysis. We compared drug use, motives, beliefs and experienced effects between heterosexual male, bisexual male and female drug-using swingers using $\chi^{2}$-tests.

Results Drug use during sex was reported by $44 \%$ (443/1005): $51 \%$ in women, $44 \%$ in bisexual men and $39 \%$ in heterosexual men $(P<0.01)$. Condomless vaginal $(46 \%)$ and anal sex (22\%) was higher in drug-using swingers (vs 34\% and 13\% in non-drug-using swingers, $\mathrm{P}<0.001)$. Among drug-using swingers, XTC (92\%), GHB (76\%) and laughing gas (69\%) were mostly used. Prolonging sex (68\%) and increasing arousal (66\%) were the most reported motives. Most reported positive effects were feeling happy (78\%) and increasing energy (78\%). Ninety-four per cent considered drug use to be pleasurable. The most reported negative effect was feeling tired (53\%), $7 \%$ reported that they might become addicted or felt uncomfortable having sex without drugs. Conclusion This study among a large group of swingers shows that drug use during sex is highly prevalent. STI clinics should discuss drug use during sex among swingers and provide information on safer sex and drug use, while acknowledging the perceived benefits, such as the increased quality of sex.

\section{INTRODUCTION}

Swingers, that is heterosexual men and women who as a couple have sex with others, are a generally older sexually-active group that show high rates of sexually transmitted infections (STI) and sexual risk behaviour, such as unprotected sex with multiple sex partners and group sex. ${ }^{1-3}$ Although swingers self-identify as heterosexual, they also engage in same-sex sexual behaviour. ${ }^{4}$ Swingers can play a role in the transmission of STI, both within their own network and to other populations. ${ }^{16}$

The use of drugs might be a determining factor for sexual risk behaviour, due to disinhibiting effects of drugs and thereby overruling of intentions to practice safe sex. ${ }^{7}$ Indeed, drug use during sex has been associated with sexual risk behaviour in swingers ${ }^{8}$ and an increased risk for STI in female swingers. ${ }^{1}$ Aside from the sexual health risks, drug use during sex has been associated with psychosocial harms, such as addiction. $^{79}$

A previous study from our research group showed that approximately 40 per cent of swingers visiting the STI clinic reported using drugs in the preceding 6 months. ${ }^{1}$ This percentage is four times higher than the estimated drug use prevalence in the general adult population in the Netherlands. ${ }^{10}$ Gamma-hydroxybutyric acid (GHB), 3,4-Methylen edioxymethamphetamine (MDMA), laughing gas, cannabis and poppers are mostly used during sex by swingers. ${ }^{1}$

The data available among swingers suggests that drug use during sex is common and associated with sexual health risks. However, we lack knowledge about the perceived benefits and risks of drug use during sex and the intention to quit drug use among swingers. This information is important to identify specific beliefs and healthcare needs of swingers and tailor STI control strategies and drug use interventions to their beliefs and needs. Tailoring ensures that prevention and care will be more effective in benefitting the individual and public health. This study assessed patterns of drug use during sex, sexual risk behaviour, motives, beliefs, experienced effects and intention to quit drug use among heterosexual male, bisexual male and female swingers in a national cross-sectional internet survey.

\section{METHODS}

\section{Data collection}

In 2018, an online survey was advertised at national swinger websites to recruit a broad sample of swingers in the Netherlands. Convenience sampling was used. A banner with a link to the survey was 
published on four (out of twelve that were approached) websites. The participating websites included two swinger dating websites, one swinger club website and one online magazine for swingers, the non-participating websites were eight swinger club websites. Participants were requested to fill in the survey individually and participate in the survey once. Participants who were 'part of a heterosexual couple and as a couple had sex with others' or 'singles who had sex with other heterosexual couples' were invited to complete the questionnaire. Participants who did not meet this definition of swinging, were aged 18 years or younger and/or did not swing in the last year were excluded from the analysis.

\section{Materials}

The online survey was developed on the basis of extensive work with swingers in STI clinical practice. The survey consisted of questions on sociodemographic characteristics, sexual behaviour, STI testing and drug use during sex. In those reporting drug use during sex, additional questions about the drug types, frequency, motives, beliefs, experienced effects and intention to quit drug use were asked. Beliefs (eg, I consider drug use during sex to be pleasurable) and intention to quit drug use during sex in the next 12 months were measured on a five-point Likert Scale (totally disagree - totally agree). Motives and experienced effects were measured by multiple choice questions, and participants had the option to provide multiple answers (questions can be found in online supplementary file I).

\section{Definitions}

Heterosexual male swingers were defined as men who reported having sex with female swing partners. Bisexual male swingers were men who reported having sex with both female and male swing partners and men who were part of a heterosexual couple who reported having sex with male swing partners. Female swingers were all women.

Sex with a condom was defined as always using a condom when having sex with swing partners. Condomless sex was defined as inconsistent condom use (ie, never, sometimes, usually) with swing partners. STI testing was defined as having had an STI test in the preceding 12 months.

Drug use during sex was defined as the use of any drug (listed in online supplementary file II) during sexual activities while swinging in the preceding 6 months, excluding alcohol and erection medicines (referred to as 'drug use during sex'). Number of drugs used was calculated as the sum of all drugs used in the preceding 6 months, and categorised into one drug, two-three drugs, four-five drugs and $\geq$ six drugs (tertiles). Alcohol use was defined as using at least three units of alcohol during one swing session.

\section{Statistical analysis}

Sociodemographic characteristics, sexual risk behaviour, STI testing, alcohol and drug use during sex were described among all participants and subgroups (heterosexual male, bisexual male and female swingers) were compared using chi-square tests or unpaired $t$-tests. Factors (swingers subgroup, age, educational level, alcohol use, condomless sex) possibly associated with drug use during sex (outcome) were tested using multivariable logistic regression analysis. The stepwise backward procedure was used, which means that variables were deleted from the model starting with the least significant one, until only significant variables remained. P-values $<0.05$ were considered statistically significant. Interaction terms between subgroup and significant factors (age, educational level, alcohol use, condomless sex) were added to the regression model to assess whether associations were different for subgroups. P-values $<0.10$ were considered statistically significant for effect modification. When there was significant effect modification, regression analyses were stratified for subgroups.

Further analyses were restricted to drug-using swingers. Descriptive statistics and chi-square tests were used to describe proportions of motives, beliefs, experienced effects, and intention to quit and differences between subgroups. P-values $<0.05$ were considered statistically significant. All analyses were performed using SPSS V21 (IBM SPSS Statistics for Windows, IBM Cooperation, Armonk, New York, USA).

\section{RESULTS}

Between May and August 2018, 1005 swingers fully completed the questionnaire which represented a completion rate of $68 \%(1005 / 1478)$ of those who started the survey but had not completed it. All 1005 participants met the inclusion criteria of recent swinging and being aged older than 18 years. More than half of participants $(58 \%, 580 / 1005)$ engaged in swinging at least once per month, 30\% (306/1005) once per 3 months and $12 \%(119 / 1005)$ one or two times per year. More heterosexual men $(40 \%, 402 / 1005)$ than bisexual men $(31 \%, 311 / 1005)$ and women $(29 \%, 292 / 1005)$ completed the survey.

\section{Characteristics of study population and subgroups}

The median age of participants was 47 years (IQR 39-54 years). Heterosexual men (median age: 48 years) and bisexual men (median age: 49 years) were older than women (median age: 42 years) (all P-values $<0.001$ ). Heterosexual men and bisexual men were more often higher educated than women $(62 \%$ and $62 \%$ vs $53 \%, \mathrm{P}=0.033$ ).

Condomless vaginal sex was reported by 39\% (393/1005), condomless oral sex by $96 \%$ (964/1005) and both did not differ between subgroups (respectively $\mathrm{P}=0.490$ and $\mathrm{P}=0.991$ ). Condomless anal sex was reported by $17 \%(170 / 1005)$ and was higher among bisexual male (19\%) and female swingers (19\%) than heterosexual male swingers $(13 \% ; \mathrm{P}<0.001)$. STI testing was reported by $64 \%$ and was similar for subgroups $(p=0.051)$. The STI clinic (44\%) and general practitioner (40\%) were the most reported testing locations for all subgroups (online supplementary file III).

\section{Drug and alcohol use during sex}

Drug use during sex in the preceding 6 months was reported by $44 \%(443 / 1005)$ (95\% CI: $41 \%$ to $47 \%)$ of all participants: 51\% among women (149/292), 44\% among bisexual men (137/311) and 39\% (157/402) among heterosexual men $(\mathrm{P}=0.002)$. Using at least three units of alcohol during sex was reported by $42 \%(418 / 1005)$ and did not differ between subgroups.

\section{Drug use during sex, condomless sex and STI testing}

Condomless vaginal sex was reported by $46 \%$ among drug-using swingers (compared with $34 \%$ in non-drug-using swingers, $\mathrm{P}<0.001$ ), condomless anal sex by $22 \%$ in drug-using swingers (compared with $13 \%$ in non-drug-using swingers, $\mathrm{P}<0.001$ ) and condomless oral sex by $98 \%$ in drug-using swingers (compared with $95 \%$ in non-drug-using swingers, $\mathrm{P}=0.020$ ). STI testing was reported by $75 \%$ drug-using swingers (compared with $56 \%$ in non-drug-using swingers, $\mathrm{P}<0.001$ ). The STI clinic was 
Table 1 Logistic regression analysis with drug use during sex in the preceding six months as outcome among all participants

\begin{tabular}{|c|c|c|c|c|}
\hline & All participants $(n=1005)$ & $\begin{array}{l}\text { Drug use during sex } \\
(n=443)\end{array}$ & & \\
\hline & $\%$ of total (n) & $\%$ within groups (n) & OR $(95 \% \mathrm{Cl})$ & $\mathrm{aOR}+(95 \% \mathrm{Cl})$ \\
\hline \multicolumn{5}{|l|}{ Swingers' subgroup } \\
\hline Heterosexual male & $40.0(402)$ & $39.1(157)$ & 1 & 1 \\
\hline Bisexual male & $30.9(311)$ & $44.1(137)$ & 1.23 (0.91 to 1.66$)$ & $1.19(0.87$ to 1.63$)$ \\
\hline Female & $29.1(292)$ & $51.0(149)$ & $1.63(1.20 \text { to } 2.21)^{* *}$ & $1.88(1.35 \text { to } 2.60)^{* * *}$ \\
\hline \multicolumn{5}{|l|}{ Age group $\ddagger$} \\
\hline $19-43$ & $34.6(347)$ & $39.8(138)$ & 1 & 1 \\
\hline $44-52$ & $36.1(362)$ & $48.9(177)$ & $1.45(1.08 \text { to } 1.95)^{*}$ & $1.52(1.11 \text { to } 2.08)^{* *}$ \\
\hline $53-74$ & $29.2(293)$ & $43.3(127)$ & $1.16(0.85$ to 1.59$)$ & 1.14 (0.81 to 1.61$)$ \\
\hline \multicolumn{5}{|l|}{ Educational level § } \\
\hline Practical & $40.9(411)$ & $47.7(196)$ & 1 & \\
\hline Theoretical & $59.1(594)$ & $41.6(247)$ & $0.78(0.61$ to 1.01$)$ & NS \\
\hline \multicolumn{5}{|l|}{ Vaginal sex } \\
\hline No/with condom 9 & $51.4(612)$ & $39.4(241)$ & 1 & 1 \\
\hline Without condom & $39.1(393)$ & $51.4(202)$ & $1.63(1.26 \text { to } 2.10)^{* * *}$ & $1.51(1.13-2.10)^{* *}$ \\
\hline \multicolumn{5}{|l|}{ Anal sex ** } \\
\hline No & $33.4(336)$ & $34.8(117)$ & 1 & 1 \\
\hline With condom & 49.7 (499) & $45.9(229)$ & $1.59(1.19 \text { to } 2.11)^{* *}$ & $1.74(1.29 \text { to } 2.34)^{* * *}$ \\
\hline Without condom & $16.9(170)$ & $57.1(97)$ & $2.49(1.71 \text { to } 3.63)^{* * *}$ & $1.98(1.29 \text { to } 3.03)^{* *}$ \\
\hline \multicolumn{5}{|c|}{$\geq 3$ units of alcohol at one swing session } \\
\hline No & $58.4(587)$ & $47.5(279)$ & 1 & 1 \\
\hline Yes & $41.6(418)$ & $39.2(164)$ & $0.71(0.55 \text { to } 0.92)^{* *}$ & $0.72(0.55 \text { to } 0.94)^{*}$ \\
\hline
\end{tabular}

Significant associations are in bold. ${ }^{* * *}<0.001,{ }^{* *}<0.01,{ }^{*}<0.05$.

As condomless oral sex was reported by $96 \%$ (964/1005), oral sex was not included in this analysis.

†Stepwise backward regression model, non-significant factors were deleted from the model: educational level.

¥Age groups were based on tertile distributions. The age of three participants was missing and excluded pairwise from analysis.

§Educational level categories were based definitions used by the Statistics Netherlands (www.//cbs.nl).

ๆCategories no and with condom were combined into one low-risk category: only 23 participants reported no vaginal sex.

${ }^{*}$ *Anal sex was independently associated with drug use during sex (aOR: $\left.1.56(1.06-2.30)^{*}\right)$

NS, Not significant.

the most reported STI testing location in drug-using swingers ( $57 \%$ vs $31 \%$ in non-drug using swingers, $\mathrm{P}<0.001)$ and the general practitioner in non-drug-using swingers $(49 \%$ vs $31 \%$, $\mathrm{P}<0.001)$.

\section{Drug use during sex and associated determinants}

In the multivariable model, being a woman, aged $44-52$ years (compared with aged 19-43 years), having condomless vaginal sex, anal sex with condom, condomless anal sex and no alcohol use were independently associated with drug use during sex (table 1). The association between alcohol use and drug use during sex differed significantly for subgroups $(\mathrm{P}=0.080$, significant effect modification). The use of at least three units of alcohol during one swing session was significantly associated with no drug use during sex only in women (aOR: $0.48,95 \% \mathrm{CI}$ : 0.30 to 0.77$)$.

\section{Patterns of drug use among drug-using swingers}

Among drug-using swingers, XTC/MDMA (92\%, 409/443), GHB/GBL $(76 \%, 338 / 443)$ and laughing gas $(69 \%, 304 / 443)$ were the most reported drugs. None of the swingers reported to have injected drugs. Half of drug-using swingers reported to use drugs during sex once per month. The use of four or more different drugs during sex in the preceding 6 months was reported by $69 \%(305 / 443)$. No differences in the drugs used or use patterns were found between subgroups (table 2).

\section{Motives, beliefs and experienced effects among drug-using swingers}

The majority of heterosexual male, bisexual male and female drugusing swingers indicated to consider drug use during sex to be pleasurable (94\%), acceptable (84\%) and exciting (66\%) (table 3). The most reported motives for using drugs were prolonged sex (68\%), increased arousal (66\%), decreased inhibitions (64\%) and intensification of sexual sensations $(61 \%)$. Prolonged sex was more important for men than women $(\mathrm{P}<0.001)$. Increased energy $(78 \%)$, happy feeling $(78 \%)$ and lovingly/intimate feeling $(77 \%)$ were the most reported experienced positive effects for all subgroups (table 3).

Half of respondents considered drug use during sex to be unhealthy $(47 \%)$ but only a minority considered drug use to be unwise (14\%) or dangerous (15\%) (table 4). Feeling tired (53\%) was the most reported experienced negative effect and this was more often reported by women than men $(\mathrm{P}=0.012)$. One in four reported that drug use during sex had a negative effect on their health. One in five reported to feel depressed the days after using drugs during sex and this was more often reported by heterosexual male and female swingers than bisexual male swingers $(\mathrm{P}=0.013)$. Only $4 \%$ had the intention to quit drug use. This percentage was higher among women than heterosexual men and bisexual men $(\mathrm{P}=0.017)$ (table 4).

\section{DISCUSSION}

This large study shows that almost half of swingers who completed an online survey in the Netherlands reported drug 
Table 2 Drug types, frequency of drug use, number of drug types compared between heterosexual, bisexual men and women who reported drug use during sex in the preceding six months $(n=443)$

\begin{tabular}{|c|c|c|c|c|c|}
\hline & $\begin{array}{l}\text { Drug-using swingers } \\
(n=443) \\
\% \text { of total }(n)\end{array}$ & $\begin{array}{l}\text { Heterosexual male drug- } \\
\text { using swingers } \\
\text { ( } n=157) \\
\% \text { of total }(n)\end{array}$ & $\begin{array}{l}\text { Bisexual male drug- } \\
\text { using swingers } \\
\text { ( } n=137) \\
\% \text { of total }(n)\end{array}$ & $\begin{array}{l}\text { Female drugs-using } \\
\text { swingers } \\
\text { ( } n=149) \\
\% \text { of total }(n)\end{array}$ & P-value \\
\hline Frequency drug use during sex & & & & & 0.401 \\
\hline Once per month & $51.0(226)$ & $52.9(83)$ & $46.7(64)$ & $53.0(79)$ & \\
\hline 2-3 times per month & $34.8(154)$ & $33.1(52)$ & $37.2(51)$ & $34.2(51)$ & \\
\hline Once per week & $10.6(47)$ & $12.1(19)$ & $9.5(13)$ & $10.1(15)$ & \\
\hline Several times per week & $3.6(16)$ & $1.9(3)$ & $6.6(9)$ & $2.7(4)$ & \\
\hline Number of drug types used & & & & & 0.257 \\
\hline 1 drug & $7.7(34)$ & $7.6(12)$ & $4.4(6)$ & $10.7(16)$ & \\
\hline $2-3$ drugs & $23.3(103)$ & $25.5(40)$ & $24.8(34)$ & $19.5(29)$ & \\
\hline $4-5$ drugs & $30.0(133)$ & $33.1(52)$ & 27.7 (38) & $28.9(43)$ & \\
\hline$\geq 6$ drugs & $38.8(172)$ & $33.8(53)$ & $43.1(59)$ & $40.3(60)$ & \\
\hline XTC/MDMA & $92.3(409)$ & $91.1(143)$ & $91.2(125)$ & $94.6(141)$ & 0.410 \\
\hline GHB/GBL & $76.3(338)$ & $75.2(118)$ & $78.8(108)$ & $75.2(112)$ & 0.700 \\
\hline Laughing gas & $68.6(304)$ & $69.4(109)$ & 71.5 (98) & $65.1(97)$ & 0.487 \\
\hline Cannabis & $50.6(224)$ & $50.3(79)$ & $51.1(70)$ & $50.3(75)$ & 0.989 \\
\hline Poppers & 46.7 (207) & $39.5(62)$ & $51.1(70)$ & $50.3(75)$ & 0.076 \\
\hline Ketamine & 47.7 (71) & $45.2(71)$ & $49.6(68)$ & $47.7(71)$ & 0.749 \\
\hline Speed & $30.0(133)$ & 29.9 (47) & 28.5 (39) & $31.5(47)$ & 0.851 \\
\hline Cocaine & $21.2(94)$ & $24.8(39)$ & $19.7(27)$ & $18.8(28)$ & 0.384 \\
\hline 4-FA & $7.4(33)$ & $7.0(11)$ & $6.6(9)$ & $8.7(13)$ & 0.763 \\
\hline $2-C B$ & $5.0(22)$ & $3.2(5)$ & $8.0(11)$ & $4.0(6)$ & 0.149 \\
\hline Crystal meth & $1.6(7)$ & $1.3(2)$ & $2.2(3)$ & $1.3(2)$ & 0.800 \\
\hline $3 \mathrm{MMC}$ & $3.4(15)$ & $3.2(5)$ & $4.4(6)$ & $2.7(4)$ & 0.760 \\
\hline Mephedrone & $2.9(13)$ & $3.2(5)$ & $4.4(6)$ & $1.3(2)$ & 0.314 \\
\hline Heroin & $0.2(1)$ & $0.6(1)$ & NA & NA & NA \\
\hline Naphyrone & $1.0(0)$ & NA & NA & NA & NA \\
\hline Magic mushrooms & $4.1(18)$ & $5.1(8)$ & $2.9(4)$ & $4.0(6)$ & 0.657 \\
\hline MXE & $1.8(8)$ & $0.6(1)$ & $1.5(2)$ & $3.4(5)$ & 0.203 \\
\hline Basecoke & $1.4(6)$ & $1.3(2)$ & $1.5(2)$ & $1.3(2)$ & 0.991 \\
\hline
\end{tabular}

P-values of $\chi^{2}$ tests or Fisher exact tests (if cells have an expected count less than 5).

Significant differences between subgroups are in bold.

2-CB, 2,5-dimethoxy-4-bromophenethylamine; 4-FA, 4-Fluoroamphetamine; GHB/GBL, Gamma-hydroxybutyric acid/Gamma-butyrolactone; 3 MMC, 3-Methylmethcathinone;

MXE, Methoxetamine; NA, Not applicable; XTC/MDMA, Ecstasy/3,4-Methylenedioxymethamphetamine.

use during sex (44\%) and this finding is in line with a previous study among swingers visiting the STI clinic in the Netherlands. ${ }^{1}$ Another online survey among swingers in Belgium found a drug use prevalence of $19 \%{ }^{8}$ One possible explanation for the lower drug use prevalence found in the study of Platteau et al ${ }^{8}$ could be that some drug types, such as laughing gas, were not included in the definition of drug use. Our study shows that XTC/MDMA, $\mathrm{GHB} / \mathrm{GBL}$ and laughing gas were the most popular drugs. The majority of drug-using swingers used four or more different drugs in the preceding 6 months.

We found an independent association between being a female swinger and drug use during sex. This difference was not found in previous studies, ${ }^{18}$ but these studies did not differentiate between heterosexual and bisexual male swingers. These studies ${ }^{18}$ compared female swingers with all male swingers, whereas drug use seems to be higher among bisexual male swingers than heterosexual male swingers. In the general population, recreational drug use is mostly higher among men compared with women. ${ }^{10}$ A possible explanation might be that women more often take drugs during sex to be physically and mentally capable of receiving esoteric sex acts with multiple sex partners by increasing arousal levels and facilitating easier intercourse. We did not observe differences in the specific drugs used or drug use patterns between heterosexual male, bisexual male and female swingers, but it should be noted that some drugs were used by too few participants to be able to detect differences between subgroups. Drug use patterns among swingers seem to be comparable with MSM with regard to the drug use prevalence during sex, ${ }^{11} 12$ the drugs used ${ }^{12}{ }^{13}$ and polydrug use. ${ }^{11}$ Nevertheless, the use of laughing gas during sex seems to be more common among swingers than MSM.

Condomless vaginal and anal sex were associated with drug use during sex, and this finding was in line with previous studies. ${ }^{18}$ Anal sex with a condom was also associated with drug use during sex, but this was due to the fact that anal sex in itself was reflected by this measure and having anal sex was associated with drug use during sex. The high drug use prevalence and its association with sexual risk behaviour indicate that swingers are an important target population for prevention strategies. These strategies should address the practice of safer sex in all swingers along with drug use-related harm reduction in drug-using swingers, such as the provision of information on safer drug use and psychosocial support. STI clinics are frequently visited by swingers. $^{214}$ Our study shows that more drug-using swingers 
Table 3 Motives, positive beliefs and experiences of drug use during sex compared between heterosexual, bisexual male and female swingers who reported drug use during sex

\begin{tabular}{|c|c|c|c|c|c|}
\hline & $\begin{array}{l}\text { All participants } \\
(\mathrm{n}=443)\end{array}$ & $\begin{array}{l}\text { Heterosexual male } \\
\text { swingers } \\
(n=157)\end{array}$ & $\begin{array}{l}\text { Bisexual male swingers } \\
(n=137)\end{array}$ & $\begin{array}{l}\text { Female swingers } \\
(\mathrm{n}=149)\end{array}$ & \\
\hline & $\%(n)$ & $\%(n)$ & $\%(n)$ & $\%(n)$ & P-value \\
\hline \multicolumn{6}{|l|}{ Motives* } \\
\hline Prolonged sex & $67.9(301)$ & 74.5 (117) & $76.6(105)$ & $53.0(79)$ & $<0.001$ \\
\hline Increased arousal & $66.4(294)$ & $65.6(103)$ & $70.8(97)$ & $63.1(94)$ & 0.371 \\
\hline Decreased inhibitions & $64.3(285)$ & $65.0(102)$ & $62.8(86)$ & $65.1(97)$ & 0.900 \\
\hline Intensification sexual sensations & $61.2(271)$ & $61.1(96)$ & $65.0(89)$ & $57.7(86)$ & 0.454 \\
\hline Increased sexual desire & $43.1(191)$ & $45.2(71)$ & $46.0(63)$ & $38.3(57)$ & 0.334 \\
\hline Increased intimacy & $42.7(189)$ & $40.1(63)$ & $51.1(70)$ & $37.6(56)$ & 0.051 \\
\hline Increased quality of sex & $40.0(177)$ & $42.0(66)$ & $48.9(67)$ & $29.5(44)$ & 0.003 \\
\hline Increased self-confidence & $26.2(116)$ & $28.0(44)$ & $19.7(27)$ & $30.2(45)$ & 0.098 \\
\hline Group sex & $13.3(59)$ & $15.3(24)$ & $16.8(23)$ & $8.1(12)$ & 0.052 \\
\hline Partners more attractive & $12.2(54)$ & $15.3(24)$ & $13.1(18)$ & $8.1(12)$ & 0.129 \\
\hline Experimenting & $6.1(27)$ & $5.1(8)$ & $5.1(7)$ & $8.1(12)$ & 0.485 \\
\hline Decreased pain & $5.4(24)$ & $1.3(2)$ & $6.6(9)$ & $8.7(13)$ & 0.005 \\
\hline Everybody does it & $2.7(12)$ & $1.9(3)$ & $2.2(3)$ & $4.0(6)$ & 0.490 \\
\hline Social pressure & $2.2(10)$ & $1.3(2)$ & $1.5(2)$ & $4.0(6)$ & 0.287 \\
\hline Craving & $1.6(7)$ & $2.5(4)$ & $0.7(1)$ & $1.3(2)$ & 0.574 \\
\hline Being part of a community & $1.6(7)$ & $0.6(1)$ & $1.5(2)$ & $2.7(4)$ & 0.343 \\
\hline Less concerns STI & $0.2(1)$ & $0.0(0)$ & $0.7(1)$ & $0.0(0)$ & NA \\
\hline \multicolumn{6}{|l|}{ Positive beliefs: drug use during sex is $\dagger$} \\
\hline Pleasurable & $93.9(416)$ & $93.0(146)$ & $92.0(126)$ & $96.6(144)$ & 0.187 \\
\hline Acceptable & $84.4(374)$ & $85.4(134)$ & $84.7(116)$ & $83.2(124)$ & 0.873 \\
\hline Exciting & $65.7(291)$ & $69.4(109)$ & $59.1(81)$ & $67.8(101)$ & 0.147 \\
\hline \multicolumn{6}{|l|}{ Experienced positive effects* } \\
\hline Happy feeling & $78.3(347)$ & $81.5(128)$ & $73.7(101)$ & $79.2(118)$ & 0.261 \\
\hline Increased energy & $77.9(345)$ & $79.6(125)$ & $81.8(112)$ & $72.5(108)$ & 0.141 \\
\hline Lovingly/intimate feeling & $76.7(340)$ & $76.4(120)$ & $83.2(113)$ & $71.1(106)$ & 0.051 \\
\hline Decreased inhibitions & $73.4(325)$ & $68.2(107)$ & $73.7(101)$ & $78.5(117)$ & 0.120 \\
\hline Relaxed feeling & $69.1(306)$ & $68.8(108)$ & $66.4(91)$ & $71.8(107)$ & 0.612 \\
\hline Increased arousal & $60.0(266)$ & $57.3(90)$ & $67.2(92)$ & $56.4(84)$ & 0.119 \\
\hline Intensified experience of light and sound & $46.5(206)$ & $47.8(75)$ & $47.4(65)$ & $44.3(66)$ & 0.801 \\
\hline More comfortable in making physical contact & $41.5(184)$ & $43.9(55)$ & $46.7(64)$ & $34.2(51)$ & 0.074 \\
\hline Postponed orgasm & $41.3(183)$ & $55.4(87)$ & $56.9(78)$ & $12.1(18)$ & $<0.001$ \\
\hline Intensified orgasm & $37.2(165)$ & $29.3(46)$ & $39.4(41)$ & $43.6(65)$ & 0.027 \\
\hline Making contacts easier & $33.2(147)$ & $36.3(57)$ & $38.7(53)$ & $24.8(37)$ & 0.024 \\
\hline Less aware of place and time & $30.0(133)$ & $31.2(49)$ & $27.0(37)$ & $31.5(47)$ & 0.647 \\
\hline Being able to have harder sex & $23.7(105)$ & $19.1(30)$ & $24.1(33)$ & $28.2(42)$ & 0.171 \\
\hline Forget my problems & $20.3(90)$ & $17.8(28)$ & $22.6(31)$ & $20.8(15)$ & 0.583 \\
\hline Being more alert & $11.1(49)$ & $11.5(18)$ & $10.2(14)$ & $11.4(17)$ & 0.930 \\
\hline Feeling comfortable days after using & $8.6(38)$ & $8.9(14)$ & $12.4(17)$ & $4.7(7)$ & 0.058 \\
\hline
\end{tabular}

P-values of $\chi^{2}$ tests or Fisher exact tests (if cells have an expected count less than 5 ).

Significant differences between subgroups are in bold.

${ }^{*}$ All possible answering options on multiple choice questions are displayed.

tScales (4: agree, 5 : totally agree) are displayed.

NA, not applicable.

than non-drug-using swingers reported STI testing, indicating self-selection for STI testing in drug-using swingers. The STI clinic was the most reported STI testing location for drug-using swingers. STI clinics could therefore play an important role in delivering these prevention strategies. However, swingers are often under-recognised in STI clinics. A previous study showed that half of STI clinic-attending swingers whose sexual behaviour is in line with the swinger definition do not identify themselves to be a swinger. ${ }^{15}$ Moreover, many STI clinics internationally do not specifically ask about swinging behaviour ${ }^{15}$ and drug use during sex. Therefore, a first step would be to openly discuss (a) swinging behaviour in STI clinics and (b) drug use during sex.

When delivering health information on safer sex and drug use, it is important to tailor messages to the beliefs and perceptions of the target population to increase people's motivation and ability to process the message carefully, thereby increasing the chance of persistent changes in behaviour. ${ }^{16}$ Our study shows that drugs were mostly used to increase the perceived quality of 
Table 4 Negative beliefs, experiences and intention to quit drug use during sex compared between heterosexual, bisexual male and female swingers who reported drug use during sex.

\begin{tabular}{|c|c|c|c|c|c|}
\hline & $\begin{array}{l}\text { All participants } \\
(n=443)\end{array}$ & $\begin{array}{l}\text { Heterosexual male } \\
\text { swingers } \\
(n=157)\end{array}$ & $\begin{array}{l}\text { Bisexual male swingers } \\
(\mathrm{n}=137)\end{array}$ & $\begin{array}{l}\text { Female swingers } \\
(n=149)\end{array}$ & \\
\hline & $\%(n)$ & $\%(n)$ & $\%(n)$ & $\%(n)$ & P-value \\
\hline Unhealthy & $46.7(207)$ & $46.5(73)$ & $46.7(64)$ & $47.0(70)$ & 0.996 \\
\hline Unwise & $13.8(61)$ & $13.4(21)$ & $10.2(14)$ & $17.4(26)$ & 0.203 \\
\hline Feeling tired days after using & $53.3(236)$ & $49.0(77)$ & $47.4(65)$ & $63.1(94)$ & 0.012 \\
\hline Damaging my health & $25.5(113)$ & $23.6(37)$ & $27.0(37)$ & $26.2(39)$ & 0.774 \\
\hline Feeling depressed the days after using & $20.3(90)$ & $22.3(35)$ & $12.4(17)$ & $25.5(38)$ & 0.013 \\
\hline Functioning less well at work days after using & $16.0(71)$ & $17.8(28)$ & $15.3(21)$ & $14.8(22)$ & 0.741 \\
\hline Having less energy for my kids days after using $\ddagger$ & $14.9(48)$ & $15.7(19)$ & $14.3(15)$ & $14.6(14)$ & 0.951 \\
\hline Possibility of addiction & $7.4(33)$ & $8.9(14)$ & $6.6(9)$ & $6.7(10)$ & 0.689 \\
\hline Need higher dose of drugs to get the same effects & $3.8(17)$ & $5.7(9)$ & $4.4(6)$ & $1.3(2)$ & 0.092 \\
\hline Intention to quit drug use in the next 12 months* & $3.6(16)$ & $3.2(5)$ & $0.7(1)$ & $6.7(10)$ & 0.017 \\
\hline
\end{tabular}

P-values of $\chi^{2}$ tests or Fisher exact tests (if cells have an expected count less than 5 ).

Significant differences between subgroups are in bold.

${ }^{*}$ Scales (4: agree, 5: totally agree) are displayed.

†All possible answering options on multiple choice questions are displayed.

$\ddagger$ Only among participants who reported to have children $(n=713)$.

sex by prolonging sex, increasing arousal and decreasing inhibitions, and this was similar for subgroups. On average, drug-using swingers had more positive than negative beliefs on drug use. The majority thought that drug use during sex was pleasurable, acceptable and exciting. When delivering information about possible sexual and psychosocial health risks of drug use during sex it is important to acknowledge these perceived benefits, such as the increased quality of sex. Prolonging sex and postponing an orgasm might be more important topics to discuss with men, and decreasing pain might be more important for women. Only a minority indicated an intention to quit drug use. These results suggest that the majority of drug-using swingers might not consider their drug use to be problematic. Nevertheless, half of drug-using swingers felt tired the days after using, one in four reported that drug use had a negative effect on their health and one in five felt depressed the days after using drugs during sex. Seven per cent indicated that they might become addicted or felt uncomfortable to have sex without drugs. STI clinics could ask drug-using swingers about these negative experiences and, when needed, refer them to addiction or mental healthcare services.

To our knowledge, this is one of the first studies that assessed drug use during sex among swingers. Another strength of our study is the reach of a large group of swingers by advertising the survey on several swinger websites. Swingers are a hidden population for research and their behaviour is under-studied. Moreover, we assessed a large variety of different aspects of drug use during sex and we compared these aspects between heterosexual male, bisexual male and female swingers. Nevertheless, our study should be viewed in light of some limitations. It should be noted that all answers were self-reported, which gave insight into the beliefs and experiences of swingers, but we could not provide proportions of drug-using swingers who would meet the clinical diagnosis of depression or addiction. Another general limitation of this study was the lack of information on swingers who did not participate in the survey. Therefore, we cannot ensure that the results can be generalised to the total population of swingers in the Netherlands. As virtual venues, such as the internet, are more often used by drug-using swingers to meet with swing partners than physical venues, such as clubs, ${ }^{4}$ the drug use prevalence might have been overestimated. However, the prevalence estimates of drug use were comparable with a previous study that recruited swingers at STI clinics in the Netherlands. ${ }^{1}$ Another limitation of this study was the cross-sectional design. We were unable to assess causal relationships between drug use and determinants. Beliefs and other psychosocial determinants were not measured among swingers who did not use drugs, which limited our assessment of determinants of drug use to sociodemographic characteristics, sexual risk behaviour and alcohol use.

\section{CONCLUSION}

This study shows that drug use during sex is highly prevalent among swingers and associated with condomless sex. This indicates that STI clinics should not only ask about drug use during sex among MSM, but also among swingers. When providing

\section{Key messages}

- Drug use during sex was highly prevalent among swingers $(44 \%)$.

- Condomless sex was higher among drug-using swingers than non-drug using swingers.

- When providing health information about safer sex and drug use, it is important to acknowledge swingers' perceived benefits, such as the increased quality of sex. 
information about safer sex and drug use during sex, it is important to acknowledge the perceived benefits of drug use during, such as the increased quality of sex. Seven per cent indicated that they might become addicted or felt uncomfortable to have sex without drugs. STI clinics could ask about these negative experiences and, when needed, refer them to addiction or mental healthcare services.

\section{Handling editor Joseph D Tucker}

Contributors All authors were involved in the conception and design of the study. CK and FK produced the database, YE analyzed the data and wrote the first draft of the manuscript. $\mathrm{CH}, \mathrm{ND}$ and $\mathrm{GVL}$ contributed to writing the paper. All authors were involved in the final manuscript.

Funding The authors have not declared a specific grant for this research from any funding agency in the public, commercial or not-for-profit sectors.

Competing interests None declared.

Patient consent for publication Not required.

Ethics approval Ethical approval was provided by the medical ethical committee of the Radboud University Medical Centre (study nr: 2018-4217). Data were registered in a fully anonymised and de-identified manner. To join the awarding of a dinner voucher of 50 euros, participants were directed to a separate survey where they could fill in their email address only for the use of sending the incentive.

Provenance and peer review Not commissioned; externally peer reviewed.

Data availability statement Data are available upon reasonable request.

ORCID iDs

Ymke J Evers http://orcid.org/0000-0003-3859-0168

Geneviève A F S van Liere http://orcid.org/0000-0002-9286-4548

\section{REFERENCES}

1. Spauwen LWL, Niekamp A-M, Hoebe CJPA, et al. Drug use, sexual risk behaviour and sexually transmitted infections among swingers: a cross-sectional study in the Netherlands. Sex Transm Infect 2015;91:31-6.

2. Dukers-Muijrers NHTM, Niekamp A-M, Brouwers EEHG, et al. Older and swinging; need to identify hidden and emerging risk groups at STI clinics. Sex Transm Infect 2010;86:315-7.
3. Dukers-Muijrers NHTM, van Rooijen MS, Hogewoning A, et al. Incidence of repeat testing and diagnoses of Chlamydia trachomatis and Neisseria gonorrhoea in swingers, homosexual and heterosexual men and women at two large Dutch STI clinics, 2006-2013. Sex Transm Infect 2017;93:383-9.

4. Niekamp A-M, Mercken LAG, Hoebe CJPA, et al. A sexual affiliation network of swingers, heterosexuals practicing risk behaviours that potentiate the spread of sexually transmitted infections: a two-mode approach. Soc Networks 2013;35:223-36.

5. O'Byrne P, Watts J. Exploring sexual networks: a pilot study of swingers' sexual behaviour and health-care seeking practices. Can J Nurs Res 2011;43:80-97.

6. Gorbach PM, Stoner BP, Aral SO, et al. "It takes a village": understanding concurrent sexual partnerships in Seattle, Washington. Sex Transm Dis 2002;29:453-62.

7. Knoops L, Bakker I, Tina VBR. Tina \& slammen: MSM, crystal meth-gebruik en het injecteren van drugs in een seksuele setting. Amsterdam: Mainline, SOA Aids Nederland, 2015.

8. Platteau T, van Lankveld J, Ooms L, et al. Sexual behaviour and sexually transmitted infections among swingers: results from an online survey in Belgium. J Sex Marital Ther 2017:43:709-19.

9. Maxwell S, Shahmanesh M, Gafos M. Chemsex behaviours among men who have sex with men: a systematic review of the literature. Int J Drug Policy 2019;63:74-89.

10. Trimbos. Nationale Drug Monitor, Netherlands 2017. Available: https://www. trimbos.nl/docs/f8502344-4a38-4a87-9740-bc408805e2fa.pdf?_ga=2.78597716. 1384399806.1549458891-521735020.1549458891

11. Daskalopoulou M, Rodger A, Phillips AN, et al. Recreational drug use, polydrug use, and sexual behaviour in HIV-diagnosed men who have sex with men in the UK: results from the cross-sectional ASTRA study. Lancet HIV 2014;1:e22-31.

12. Heiligenberg $M$, Wermeling $P R$, van Rooijen MS, et al. Recreational drug use during sex and sexually transmitted infections among clients of a city sexually transmitted infections clinic in Amsterdam, the Netherlands. Sex Transm Dis 2012;39:518-27.

13. Drückler $S$, van Rooijen MS, de Vries HJC. Chemsex among men who have sex with men: a sexualized drug use survey among clients of the Sexually Transmitted Infection Outpatient Clinic and users of a gay dating app in Amsterdam, the Netherlands. Sex Transm Dis 2018:45:325-31.

14. Bodley-Tickell AT, Olowokure B, Bhaduri S, et al. Trends in sexually transmitted infections (other than HIV) in older people: analysis of data from an enhanced surveillance system. Sex Transm Infect 2008;84:312-7.

15. Spauwen LWL, Niekamp A-M, Hoebe CJPA, et al. Do swingers self-identify as swingers when attending STI services for testing? A cross-sectional study. Sex Transm Infect 2018;94:559-61.

16. Witte K. Fishing for success: Using the persuasive health message framework to generate effective campaign messages. In: Maibach E, Parrott RL, eds. Designing health messages: Approaches from communication theory and public health practice. Thousand Oaks, CA: Sage, 1995: 145-66. 